grotesque caricature of reality". Teachers, the respondents seemed to suggest, were people who undertook the job for no better reason than family tradition or a desire for safety and security, needed little training, and once in the job spent little time in maintaining proper standards or increasing their productivity. Most informants at the same time said that teachers ought to do the job from a sense of vocation, and implied that it was sordid and undesirable to expect a decent salary.

At the same time, it is hard to escape from the feeling that the NUT itself possesses a somewhat unreal notion of the teacher. The majority, it says, enter teaching for idealistic reasons, for the sense of vocation and social responsibility, and from an awareness of the key role of education. There are no figures on which to base this claim, as the NUT admits, so there seems to be little reason for the unbiased observer to give it any more credence than he does the views of the unnamed informants. It might indeed have been money better spent if the NUT had paid Research Services to interview a number of young recruits to teaching (without revealing for whom the survey was being carried out) and to see if the responses matched the high principles which the NUT believes it can detect.

Some of the informants displayed a touchingly out of date view of the profession, though it is one which will strike a chord with a good few of the older readers. One said that teachers are attracted by the fact that "they can find an outlet for domineering tendencies over children" and that "they like a captive audience". But if any of the informants were critical of the tactics adopted by the teachers in their campaigns, their comments were lost in the editing. To some people it seems that the real reason for the continuing poverty of the teachers lies in a failure to grasp the realities of the situation. The genteel tactics which they have so far used have not been successful, but they are nevertheless reluctant to turn to anything more militant. In practice, a few well organized strikes might do more good than a thousand pamphlets.

\section{BRITISH ASSOCIATION}

\section{New Man of the BA}

After three months in his new job, Dr Henry Turner, the secretary of the British Association, is enthusiastic about the future. A chemist to begin with, Dr Turner has just spent eight years as a university administrator in Sheffield, where he developed an interest in the history of science and technology and scientific methodology. His new job, with a salary which he says is in the professorial range, is very much full time. This is something of an innovation, for his recent predecessors have tended to be older, with a career of public service behind them, serving on so many committees that being secretary of the $\mathrm{BA}$ was virtually a part time occupation. Perhaps the new approach is a sign of the times, with the association striving to expand and at the same time solve its financial problems.

The most exciting and significant developments that Dr Turner sees for the future are the schemes to bring young people into the association and to separate the fees charged for membership and for attendance at the annual meeting, by which it is hoped to make the meetings self supporting. The association hopes to implement these schemes, which are still before the Privy Council, for this year's meeting at Exeter. Meanwhile, the British Association Young Scientists (BAYS) are forming local groups in several regions. The response seems to have been particularly good in the southern region, where branches have been formed from existing Young Scientists Associations. Between 60 and 70 sixth formers met last week at the Royal Society to discuss the future of BAYS, which they are to organize themselves. At present young people's activities-exhibitions, lectures, visits and so on-are organized by the local branches and area committees, which will still be available to give advice. The present lecture service, started in 1958, may continue side by side with the new BAYS organization. The scope of the activities of BAYS is intended to extend beyond the present young people's programme, and eventually to include such things as foreign travel. Central advice and coordination will come from a BAYS officer who is to be appointed soon.

The organizational basis on which BAYS branches are being formed is provided largely by the local branches and area committees, and Dr Turner sees a bright future for this aspect of the association's activities. He expects the branches to thrive and develop better programmes for local members. This should be helped by the new membership fees, for, assuming the scheme is approved by the Privy Council, half of the membership fee of $£ 2$ will go to headquarters and half will be retained by the local branch. Local authorities are proving financially helpful with young people's programmes, and industry, which has been very generous to the branches during the past ten years, is continuing to give assistance.

Dr Turner thinks that the annual meetings will continue to develop their coverage of wide general issues. At Exeter there will be symposia on inventiveness and innovation, linked with a large scale exhibition of inventions, and on the management of the natural environment. There will again be public lectures, this time on pulsars, sleep, gambling, the immunology of cancer and natural resources from the deep sea. Three other exhibitions will be concerned with topics originally discussed at the first Exeter meeting of the BA in 1869-mapping the Moon, the sea-going qualities of ships and decimal units. Recognizing the development of a new kind of lay public - scientists eager to be informed about progress in branches of science other than their own-the multidisciplinary aspect is likely to be stressed at future annual meetings, in the form of more joint activities between sections.

\section{GEOLOGICAL PROSPECTING}

\section{No Gold in Botswana}

Hopes that the economic future of Botswana (recently Bechuanaland) would be assured by the discovery of gold or other valuable mineral deposits will have to be contained a little longer, to judge from the latest report of the Geological Survey Department for the year ending December 1967 (Government Printer, Gaberones). In spite of a rising scale of expenditure on the geological survey and on the search for underground water reserves, no spectacular finds are recorded. But the economy of Botswana, sandwiched as it is between South Africa in the south and Rhodesia in the north, 